\title{
Recovery of degraded areas using topsoil in the Amazon rainforest
}

\author{
A. I. Ribeiro $^{1}$, R. M. Longo ${ }^{2}$, W. J. Melo ${ }^{3}$, R. W. Lourenço ${ }^{1}$, \\ A. J. S. Maciel ${ }^{3}$, A. H. Rosa ${ }^{1} \&$ L. F. Fraceto ${ }^{1}$ \\ ${ }^{I}$ University State of São Paulo, UNESP-Campus Sorocaba, Brazil \\ ${ }^{2}$ Pontifical Catholic University, PUC-Campinas, Brazil \\ ${ }^{3}$ State University of Campinas, UNICAMP, Brazil
}

\begin{abstract}
This study is aimed at evaluating the effect of placing the top soil cover areas, such as tailings degraded by tin mining, in the Amazon rainforest in Brazil. The evaluations of the planting sites occurred in areas where tin mining was carried out, basically planting native trees over a period of seven years. This work did not come from a pre-decreed methodology of experimental design, and data was collected only seven years after planting. Thus, it was not possible to identify all variables that contributed to a better recovery of the areas. Sampling was done about seven years after placing the "top soil" and is determined: $\mathrm{pH}$, organic matter content, $\mathrm{P}, \mathrm{K}, \mathrm{Ca}, \mathrm{Mg}, \mathrm{Al}$, cation exchange capacity (T), base saturation (V\%), B, Fe, $\mathrm{Zn}, \mathrm{Cu}$ and $\mathrm{Mn}$. The native forest species existing at the site were evaluated in relation to height (in meters) and diameter of the base. For all sites where the surface layer of soil was applied, there were significant differences in the growth of native species.

A fundamental aspect in the rehabilitation of areas degraded by mining, in general, is the knowledge about the soil where that recovery must be conducted. The specific procedures in the rehabilitation of those areas depend essentially on the physical, chemical, biological and mineralogical properties of the soil, which must present conditions for the adequate development of the plants.

The initial idea of implanting a project of recovery of soils degraded by mining in the Amazon Forest emerged from a first visit to the field, carried out in 1998. The conditions of the already mined areas, in comparison to the exuberant forest of the surroundings caught our attention. The mining company that acts in
\end{abstract}


the area had already been trying for some time to implant a plan of recovery of these mining areas, however without reaching any significant positive results.

The loss of organic matter is one of the main problems of degraded areas in Brazil. The storage and reuse of a blanket of soil (topsoil) produce excellent results, but most of the miners consider this technique expensive and difficult because of operational costs and the sharp topographical condition of the mine site.

Therefore, a research project was elaborated prioritizing the recovery of the soil degraded by the tin mining as a prior step to the recovery activities with native forest species. The formation of a superficial pseudo-horizon that supported the vegetation and the time that it would take for its establishment became the main objective of this research.

The objective of this work is to verify the levels of elements and their traces in areas where top soils were applied for the remediation of degraded areas with local re-vegetation.

\section{Material and methods}

The National Forest of Jamari, administered by the Brazilian Institute of the Environment and Renewable Mineral Resources - IBAMA, is located $90 \mathrm{Km}$ away from the city of Porto Velho - RO, by the Br-364, heading for Cuiabá/MT, being one of the most privileged areas of the North, for its geographical position and access routes (Fig. 1).

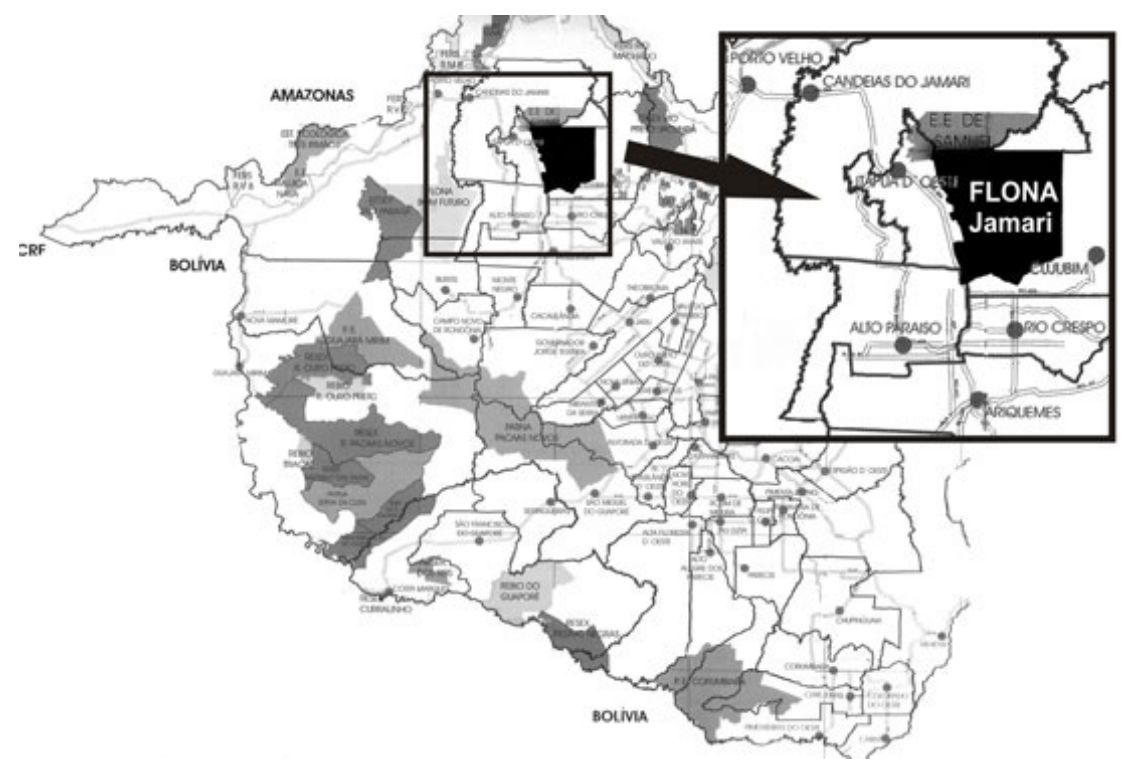

Figure 1: Location of the National Forest of Jamari/RO Font: http://www.resistenciacamponesa.com/images/stories/rc16/mapafn. jpg. 
This work is part of the monitoring program of the areas in recovery in the National Forest of Jamari in Rondônia, starting in 1999 and in partnership with universities. The amount of N, P, K, S, organic matter, B, Fe, Mn, Zn, Ca and $\mathrm{Mg}$ were determined in the soil used as cover. The topsoil was applied for remediation of degraded areas, compared with areas without topsoil applications.

Samples were removed at deposition places of reject and the areas plowed, because they occupy the largest percentage of the degraded areas and therefore needing special attention, can be observed in Figs 2 to 5 .

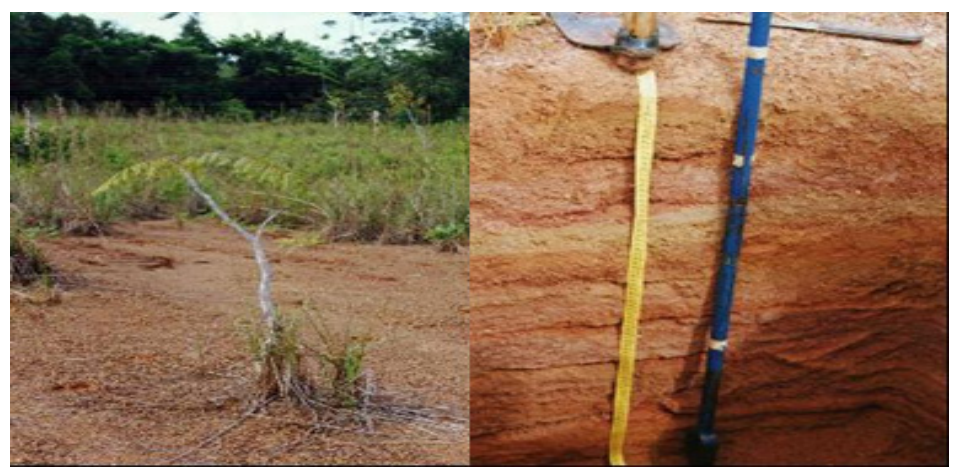

Figure 2: $\quad$ Tailings profile (non-covered soil).

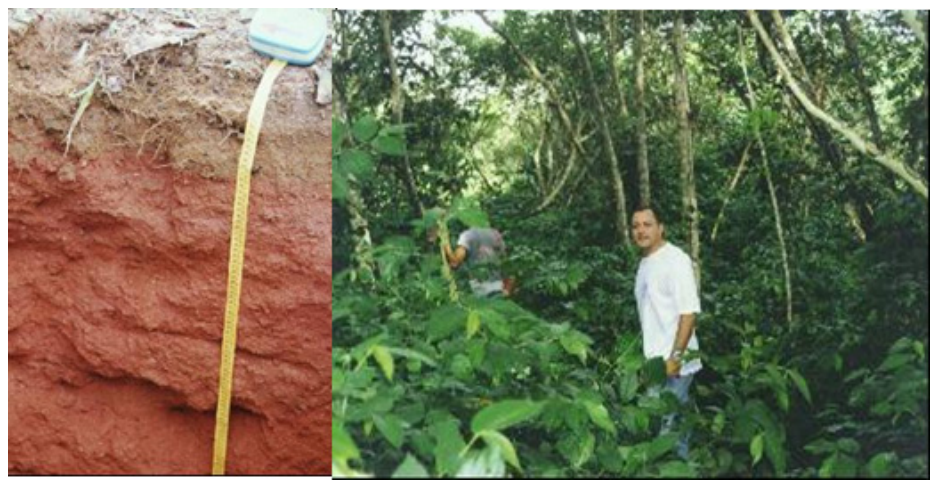

Figure 3: $\quad$ Tailings (soil covered).

The samples were collected superficially, with the help of an auger, in the layer between $0-20 \mathrm{~cm}$, in regular intervals of 20 meters, totaling 4 samples composed by an area located between the UTM coordinates latitude $0900^{\prime} 00^{\prime \prime}$ to $930^{\prime} 00^{\prime \prime} \mathrm{S}$ and longitude $6244^{\prime} 05^{\prime \prime}$ to $6316^{\prime} 54^{\prime \prime} \mathrm{W}$, containing three different areas: Poço B, Novo Mundo and Serra da Cacimba (without top soil and with top soil).

The samples were analysis in relation to the total contents of copper, iron, manganese, zinc, calcium and magnesium in treated mined soil after leguminous planting and the samples were conditioned in ice until the moment of analysis. 
The soil analyses were conducted in the Department of Technology of UNESP, in the Jaboticabal/SP campus, Brazil. The analyses were conducted according to the method proposed by [3].

The average data of each mine for each treatment were submitted to the analysis of variance by the $\mathrm{F}$ test and later comparison by the Tukey test $(\mathrm{p}=0.05)[4]$.

\section{Results and discussion}

In the first instance, a series of field investigations were conducted including soil and vegetation samplings, seeking to evaluate the performance of the recovery activities that had already been implanted by the mining company. Of what was observed, just a few hectares that were covered by a soil layer and organic residues (Figs 2 to 5), presented positive results. In Table 1 analyses of three areas that suffered this covering are presented: Area 1: "Novo Mundo"; Area 2: "Serra da Cacimba"; Area 3: "Serra da Onça". Those samples were taken in areas that suffered and did not recover, and the plantation of forest species was accomplished by the company in 1993.

Table 1: Chemical Aspects in areas with and without placement of "top soil" in Flona of Jamari/Rondônia - Brazil.

\begin{tabular}{|c|c|c|c|c|c|c|}
\hline \multirow{3}{*}{ Parameters } & \multicolumn{6}{|c|}{ Areas } \\
\hline & \multicolumn{2}{|c|}{ Poço B } & \multicolumn{2}{|c|}{ Novo Mundo } & \multicolumn{2}{|c|}{ Serra Cacimba } \\
\hline & \begin{tabular}{|c|} 
without top \\
soil
\end{tabular} & $\begin{array}{c}\text { with top } \\
\text { soil }\end{array}$ & $\begin{array}{l}\text { without } \\
\text { top soil }\end{array}$ & $\begin{array}{c}\text { with top } \\
\text { soil2 }\end{array}$ & $\begin{array}{l}\text { without } \\
\text { top soil }\end{array}$ & $\begin{array}{c}\text { with top } \\
\text { soil }\end{array}$ \\
\hline M.O. $\mathrm{mg} \mathrm{dm}^{-3}$ & $12,3 \mathrm{a}$ & $7,3 \mathrm{~b}$ & $17,0 \mathrm{a}$ & $8,5 b$ & $13,5 \mathrm{a}$ & $9,5 \mathrm{~b}$ \\
\hline $\mathrm{S}_{-\mathrm{SO}_{4}} \mathrm{mg} \mathrm{dm}^{-3}$ & $5,5 \mathrm{a}$ & $31,5 b$ & $4,0 \mathrm{a}$ & $45,0 \mathrm{~b}$ & $26,8 \mathrm{a}$ & $57,5 \mathrm{~b}$ \\
\hline $\mathrm{pH} \quad \mathrm{CaCl}_{2}$ & $3,6 a$ & $4,5 \mathrm{~b}$ & $4,2 b$ & $4,4 \mathrm{~b}$ & $4,2 \mathrm{~b}$ & $4,3 \mathrm{~b}$ \\
\hline $\mathrm{P} \mathrm{mg} \mathrm{dm}^{-3}$ & $3,8 \mathrm{a}$ & $2,5 b$ & $4,0 \mathrm{a}$ & $2,3 b$ & $2,5 b$ & $2,3 b$ \\
\hline $\mathrm{K} \mathrm{mmolc} \mathrm{dm}^{-3}$ & $0,9 \mathrm{~b}$ & $0,7 \mathrm{~b}$ & $1,2 \mathrm{a}$ & $0,5 b$ & $1,3 \mathrm{a}$ & $0,7 \mathrm{a}$ \\
\hline $\mathrm{Ca} \mathrm{mmolc} \mathrm{dm}^{-3}$ & $2,8 \mathrm{~b}$ & $1,5 \mathrm{~b}$ & $11,5 \mathrm{a}$ & $1,0 \mathrm{~b}$ & $3,5 b$ & $1,0 \mathrm{~b}$ \\
\hline $\mathrm{Mg} \mathrm{mmolc} \mathrm{dm}^{-3}$ & $1,5 b$ & $1,3 \mathrm{~b}$ & $3,8 \mathrm{a}$ & $1,0 \mathrm{~b}$ & $1,5 \mathrm{~b}$ & $1,0 \mathrm{~b}$ \\
\hline $\mathrm{Al}$ mmolc $\mathrm{dm}^{-3}$ & $13,8 \mathrm{a}$ & $1,8 \mathrm{~b}$ & $3,5 b$ & $2,0 \mathrm{~b}$ & $5,3 \mathrm{~b}$ & $3,3 \mathrm{~b}$ \\
\hline $\mathrm{H}+\mathrm{Al} \mathrm{mmolc} \mathrm{dm}^{-3}$ & $50,3 a$ & $11,3 b$ & $34,8 \mathrm{a}$ & $14,8 \mathrm{~b}$ & $32,8 \mathrm{a}$ & $28,0 \mathrm{a}$ \\
\hline SB mmolc $\mathrm{dm}^{-3}$ & $4,9 \mathrm{a}$ & $3,7 \mathrm{a}$ & $16,4 \mathrm{~b}$ & $2,5 \mathrm{a}$ & $6,3 a$ & $2,7 \mathrm{a}$ \\
\hline $\mathrm{T} \mathrm{mmolc} \mathrm{dm}^{-3}$ & $55,1 \mathrm{a}$ & $14,9 \mathrm{~b}$ & $51,2 \mathrm{a}$ & $17,3 \mathrm{~b}$ & $41,8 \mathrm{a}$ & $30,7 \mathrm{a}$ \\
\hline $\mathrm{V} \quad \%$ & $8,5 \mathrm{a}$ & $24,3 b$ & $33,3 a$ & $15,3 \mathrm{~b}$ & $16,5 \mathrm{a}$ & $9,0 \mathrm{~b}$ \\
\hline B mg.dm $^{-3}$ & $0,2 \mathrm{a}$ & $0,1 \mathrm{~b}$ & $0,2 \mathrm{a}$ & $0,2 \mathrm{a}$ & $0,2 \mathrm{a}$ & $0,2 \mathrm{a}$ \\
\hline Fe mg.dm ${ }^{-3}$ & $64,0 \mathrm{a}$ & $2,9 b$ & $33,3 \mathrm{a}$ & $1,8 \mathrm{~b}$ & $17,5 \mathrm{a}$ & $1,4 \mathrm{~b}$ \\
\hline $\mathrm{Zn} \mathrm{mg. \textrm {dm } ^ { - 3 }}$ & $0,9 \mathrm{a}$ & $0,5 \mathrm{a}$ & $1,2 \mathrm{a}$ & $0,2 \mathrm{~b}$ & $0,8 \mathrm{a}$ & $0,2 \mathrm{~b}$ \\
\hline $\mathrm{Cu} \mathrm{mg. \textrm {dm } ^ { - 3 }}$ & $0,7 \mathrm{a}$ & $0,1 \mathrm{~b}$ & $0,6 \mathrm{a}$ & $0,1 \mathrm{~b}$ & $0,3 \mathrm{~b}$ & $0,1 \mathrm{~b}$ \\
\hline 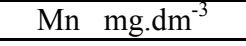 & $1,7 \mathrm{a}$ & $0,8 \mathrm{a}$ & $11,6 b$ & $0,8 \mathrm{a}$ & $3,0 \mathrm{a}$ & $1,4 \mathrm{a}$ \\
\hline Plant height $(\mathrm{m})$ & $4,4 a$ & $1,9 b$ & $10,8 \mathrm{a}$ & $1,6 \mathrm{~b}$ & $4,2 \mathrm{a}$ & $2,9 b$ \\
\hline $\begin{array}{c}\text { Plant base } \\
\text { Diameter }(\mathrm{m})\end{array}$ & $0,6 \mathrm{a}$ & $0,2 b$ & $0,9 a$ & $0,3 b$ & $0,3 \mathrm{~b}$ & $0,3 \mathrm{~b}$ \\
\hline
\end{tabular}


As we can observe, the contents of organic matter (O.M.), potassium (K), Sum of Bases (SB) and Saturation for Bases (V\%) presented significant differences that, probably, facilitated the establishment of the introduced vegetation and the spontaneous appearance of species (Figs. 4 and 5). Thus, the recovery of tailings with soils originating from ravines and forest remains, promoting alterations that facilitated a better establishment of the vegetation.

The field observations and preliminary analyses guided the subsequent works of conducting experiments in greenhouses and, later on, in the field. The definition of a source of organic matter that could be later incorporated and the improvement of the chemical, physical and biological properties of the degraded soil were the bases to the installation of those experiments.

As we can observe, the contents of organic matter (O.M.), potassium (K), Sum of Bases (SB) and Saturation for Bases $(\mathrm{V} \%)$ presented significant differences that, probably, facilitated the establishment of the introduced vegetation and the spontaneous appearance of species (Figs. 2 and 3). Thus, the recovery of tailings, with soils originating from ravines and forest remains, promoting alterations that facilitated a better establishment of the vegetation.

\section{Conclusion}

The results showed that the process of tin extraction promoted significant alterations in the properties of the soils studied. Thus, the recovery of tailings, with soils originating from ravines and forest remains, promoted alterations that facilitated a better establishment of the vegetation.

\section{Acknowledgements}

Authors acknowledge the support of the Foundation of Help to the Research of the State of São Paulo (FAPESP), Brascan Environmental Recovery and to the Brazilian Institute of the Environment and Renewable Mineral Resources (IBAMA).

\section{References}

[1] Fontes, M.P.F. Estudo pedológico reduz impacto da mineração. Revista da Cetesb de Tecnologia. AMBIENTE, São Paulo, p. 58-61, 1991.

[2] Ribeiro, Admilson. I., Mecanização do preparo de solo em áreas degradadas por mineração na floresta do Jamari, Rondônia, Brasil. FEAGRI, UNICAMP, Campinas-SP, 135p. 2005 (Tese de doutorado).

[3] Vance, E.D., Brookes, P.C., Jenkinson, A.S. Na extraction method for measuring soil microbial biomass C. Soil Biologic Biochemical, oxford, v.19, p.703-707, 1982.

[4] Banzatto, D.A., Kronka, S.N. Experimentação agrícola. 2.ed. Jaboticabal: Ed. Funep, 1992. 247p. 